First (Experimental) Report to the Atmospheric Corrosion Research Committee (of the British Non-Ferrous Metals Research Association). By W. H. J. Vernon. Presented to the Faraday Society, December I 7, I923; with Full Report of Discussion. Pp. 839-934. (London: The Faraday Society, 1924.) 7s. 6d. net. THE research by Mr. W. H. J. Vernon on the tarnishing and fogging of metals, presented to the Faraday Society on December $17, \mathrm{r}_{923}$, of which some account has already appeared in our columns (NATURE, February 2, I924, p. I78), has now been published with a full report of the discussion which took place on that occasion, together with certain communications since received. The discussion is of a thoroughly broad and representative character, and many points of view and interesting items of information were contributed. Mr. Lancaster mentioned that although it was generally considered that the purest zinc was the most difficult to dissolve in acids, Mr. Rigg, late of the New Jersey Zinc Company, had found that the purest zinc they had produced for the United States Bureau of Standards was almost explosive under acid treatment; in other words, the rate of solution was very rapid. Taken as a whole, the discussion and contributions add decidedly to the value of the report, and general unanimity was expressed that the most hopeful way of solving the practical problem of preventing the tarnishing and fogging of metals was to attack it by laboratory experiments carried out on fundamental lines of scientific inquiry.

\section{Electrical EngineERINu.}

Small Electric Generating Sets Employing Internal Combustion Engines. By W. Wilson. Pp. $16 \mathrm{r}+\mathrm{I} 6$ plates. (London: Ernest Benn, Ltd., I924.) I8s. net.

Many are interested in the small electric generating sets that are used for country-house lighting and for supplying electric power for kinematographs, radiographic outfits, etc., in isolated localities. The invention of the tungsten lamp and recent developments in internal combustion engines have made small installations highly desirable in many cases. Most of the books which deal with this subject are now becoming antiquated, so we welcome Mr. Wilson's volume, which describes the best modern practice.

The author has hit the happy mean between a book overburdened with elementary theoretical matter and one that goes into highly technical details, which are only of interest to the manufacturer. So far as lighting current is concerned, electricity can be generated by the consumer at a cost little more expensive than that charged by a public company. But if it is used for heating and power purposes, it compares very unfavourably with a city supply. For many purposes in connexion with farming, electricity can be economically employed. For illuminating yards, stables, and outbuildings it is most valuable, but it is essential to use suitable water-tight fittings. It has now been conclusively proved that the low productiveness of the hen during the winter months is not due to the want of heat, but to the want of light. The lack of daylight in winter can easily be made up by installing a fifty-watt lamp in the fowl-run. It is required from 5 A.M. until dawn and from dusk until 9 P.M. The switching can easily be done by an automatic device. Under these conditions the hens continue to lay almost as in summer, having the requisite time to take more nourishment.

Alternating Current Rectification: a Mathematical and Practical Treatment from the Engineering Vier-point.

By L. B. W. Jolley. Pp. xviii $+35^{2}$. (London :

Chapman and Hall, Ltd., I924.) 25 s. net.

ThE conversion of alternating current into current pulsating in one direction is a problem which electrical engineers have been studying for many years. In the early days of the industry, a serious drawback to the use of alternating currents for supply distribution was that there was no accumulator suitable for storing the electrical energy, and hence the alternators had to run night and day. Electrolytic valves were then invented to rectify the alternating current, so that it could be used for charging cells. In polyphase systems of supply this was accomplished mechanically by machines called rotary converters. At the present moment mercusy vapour rectifiers are employed in many towns to get direct current from an alternating supply. In connexion with radio engineering all kinds of rectifiers are used. It will be seen, therefore, that the field is a wide one and it is continually expanding.

Mr. Jolley's book opens with a good discussion of wave form, and Fourier's analysis is applied to several problems in an instructive way. The mechanical rectifiers are next discussed, including a brief description of the Highfield transverter. Then we have descriptions of mercury-vapour rectifiers and vacuum tubes. Interesting descriptions are also given of point to plate discharge, vibrating flame rectifiers, corona rectifiers, and photo-electric cell rectifiers. Finally the author discusses the conduction of electricity through liquids, a knowledge of which is necessary in order to understand electrolytic rectifiers and radio rectifiers. Numerous helpful references are given to papers and books. The book can be recommended to research engineers.

Railway Electrification: a Complete Survey of the Economics of the Different Systems of Railway Electrification from the Engineering and. Financial Points of View. By Prof. H. F. Trewman. (The Specialists' Series.) Pp. xii +244 . (London: Sir Isaac Pitman and Sons, Ltd., I924.) 25s. net.

THIS book gives a survey of the economics of the different systems of railway electrification from the engineering point of view. It is pointed out that for the last thirty years electricity has been successfully employed all over the world to operate tramways. At the beginning of the century it was adopted for elevated and tube railways. Then came the electrification of the suburban railways, and finally, mainly on the Continent and in the United States, the electrification of the main line railways. It is universally admitted that electrification of the main line railways in Great Britain is feasible; the only question about which opinions still differ is the financial one. Were it not for the War, at least two British main lines would have been rapidly extending their systems of electrification. Apparently they have adopted a policy of waiting, and so we are continuing to burn an unnecessary quantity 